\title{
Species diversity and community composition of mosquitoes in a filariasis endemic area in Banyuasin District, South Sumatra, Indonesia
}

\author{
RINI PRATIWI ${ }^{1, \vartheta}$, CHAIRIL ANWAR $^{2, v \vee}$, SALNI $^{3}$, HERMANSYAH $^{4}$, NOVRIKASARI $^{5}$, AHMAD GHIFFARI $^{6}$, \\ RADEN PUTRA ${ }^{1}$, ADRI HUDA ${ }^{1}$ \\ ${ }^{1}$ Department of Environmental Science, Graduate Program, Universitas Sriwijaya. Jl. Padang Selasa No. 524 Palembang 30139, South Sumatra, \\ Indonesia. Tel./fax. +62-711-354222, `email: dr_ninik.6575@yahoo.com. \\ ${ }^{2}$ Department of Parasitology, Faculty of Medical Science, Universitas Sriwijaya. Ogan Ilir 30662, South Sumatra, Indonesia. \\ Tel./fax. +62-711-580644, " "email: chairil53@fk.unsri.ac.id. \\ ${ }^{3}$ Department of Biology, Faculty of Mathematics and Natural Science, Universitas Sriwijaya. Ogan Ilir 30662, South Sumatra, Indonesia \\ ${ }^{4}$ Department of Chemistry, Faculty of Mathematics and Natural Science, Universitas Sriwijaya. Ogan Ilir 30662, South Sumatra, Indonesia \\ ${ }^{5}$ Department of Occupational Health and Safety, Faculty of Public Health, Universitas Sriwijaya. Ogan Ilir 30662, South Sumatra, Indonesia \\ ${ }^{6}$ Department of Parasitology, Faculty of Medical Science, Universitas Muhammadiyah Palembang. Palembang 30263, South Sumatra, Indonesia
}

Manuscript received: 23 December 2018. Revision accepted: 25 January 2019.

\begin{abstract}
Pratiwi R, Anwar C, Salni Hermansyah, Novrikasari, Ghiffari A, Putra R, Huda A. 2019. Species diversity and community composition of mosquitoes in a filariasis endemic area in Banyuasin District, South Sumatra, Indonesia. Biodiversitas 20: $453-462$. Mosquitoes are well known as the most medically important arthropod vectors which should be monitored and evaluated because of their potential to transmit diseases. One step in monitoring and evaluation could be conducted by assessing the presence of prevalent mosquito's vectors including their species diversity and composition. The present study has successfully recorded the diversity and community composition of mosquitoes in two villages in Banyuasin District, South Sumatra Province, Indonesia. The research was conducted for four months from December 2016 to March 2017 by collecting mosquitoes using Indoor and Outdoor Human Landing Collection method (HLC). The result shows that there were 8239 mosquitoes collected consisting of 12 genera and 38 species. Mansonia is found as the most dominant genus in Sedang Village, while in Muara Sugih Village, Culex is the most dominant. Assessment on species diversity showed that Sedang Village haes higher diversity compared to Muara Sugih Village. Further analysis indicates that environmental characteristics and presence of water plant play important role in the diversity, abundance, and dominance of mosquitoes. Waterlogged area covered with Pistia stratiotes in Sedang Village likely facilitate the breeding of Mansonia spp while extensive rice field in Muara Sugih Village may enable the high numbers of Culex spp. Anopheles spp. and Aedes spp. mosquitoes. The findings of this study suggest the rationale for the high cases of filariasis in Banyuasin District. Future research should be directed to reveal mosquitoes' dispersal pattern and its potential as disease vector, the risk of transmitted disease, and further prevention to reduce the number of filariasis cases.
\end{abstract}

Keywords: Disease vector, entomology, environmental characteristics, human landing method, mosquitoes diversity

Abbreviations: Ma: Mansonia; Cx: Culex; An: Anopheles; Ae: Aedes; Och: Ochlerotatus; fv: fulvus; sp./spp.: species

\section{INTRODUCTION}

Mosquitoes are important groups of arthropods which inhabit freshwater habitats. Beside causing annoyance to humans, mammals, birds and other animals due to their bites (Rueda 2008), the presence of mosquitoes is generally undesirable as they may transmit pathogen, especially to human, causing diseases such as filariasis, dengue, and malaria (Kauffman et al. 2017; Asare et al. 2016; Chandra 2008). Rueda (2008) reported that there are more than hundreds of mosquitoes species which have been proved to transmit various diseases to human and animal species.

In the context of filariasis, mosquitoes are well known as the most medically important arthropod vectors which should be monitored and evaluated because of their potential to transmit the disease (Rajakumar and Abdul Rahuman 2011). One step in monitoring and evaluation could be conducted by assessing the presence of prevalent mosquitoes vectors including their species diversity and composition (Beerntsen et al. 2000). Several studies report that there are 23 species belong to five genera which are potentially identified as filariasis vectors, such as Mansonia, Anopheles, Culex, Aedes, and Armigeres (Wijayanti et al. 2016; St. Laurent et al. 2016; Sugiarto et al. 2017). The potential of being the vector is based on several cases. For example in Mali, 10 species of Anopheles and $C x$. quinquefasciatus are confirmed as the vectors of Wuchereria bancrofti in the rural and urban type location, respectively (Coulibaly et al. 2013); and 6 Mansonia species are reported as the Brugia malayi vectors which are found in the swamp area in Thailand (Apiwathnasorn et al. 2006). Nonetheless, filariasis cases generated by mosquito species from such genera in Indonesia still rarely appear in the medical reports likely because of the lack of information. The Ministry of Health of the Republic of Indonesia reports that Mansonia and Anopheles barbirostris are the main species which play 
important role in the transmission of filariasis in eastern Indonesia (Kementerian Kesehatan RI 2016).

In South Sumatra, Ma. uniformis and An. nigerrimus are confirmed as B. malayi vectors, while An. barbirostris is reported as the vector of $B$. timori which is commonly found in East Nusa Tenggara and the South Maluku Islands (Kementerian Kesehatan RI 2016). Some species of Mansonia spp. are also reported as the nocturnal subperiodic of $B$. malayi vectors. In general, comprehensive research to identify vectors of infectious diseases has never been made in Indonesia. The diversity of mosquitoes, for example, has never been reported comprehensively despite the fundamental role of such data in informing the potential risk and impact of the transmission of infectious diseases and the plausible preventive actions to control the transmission (Vourc'h et al. 2012; Chaves et al. 2011). The lack of information on species diversity of mosquito hampers the understanding on the distribution and occurrence of vectors potentially initiate the infectious disease.

In this study, diversity of mosquito species is investigated for the first time in two villages in Banyuasin District, South Sumatra, Indonesia to assess the potential of transmission of filariasis and other mosquitoes-based infectious diseases in the area. The choice of the studied area is based on the high filariasis cases occurred during the periods between 1983 and 2002. Banyuasin is also reported as the highest filariasis cases in South Sumatra as in 2014 there were $83 \%$ (142 of 173) of provincial cases of chronic filariasis occurred in Banyuasin District alone (Dinas Kesehatan Banyuasin 2016). Banyuasin also has a high rate of endemic case with $2.02 \%$ of the average microfilariae rate. The high rates of filariasis and endemic cases indicates the high abundance of mosquitoes which potentially increases the possibility of pathogen transmission (Roche et al. 2013). Several efforts have been made to suppress the number of filariasis cases in Banyuasin District including fogging, community counseling, and treating the villagers through the mass drug administration (MDA) programmes (Banyuasin 2016). However, the number of cases is still relatively high with the microfilaria rate of $0.93 \%$ after three years of the MDA program.

Furthermore, this study also aims to investigate the community composition of mosquito species in term of abundance, frequency, and dominance as well as their habitats and resting rate in Banyuasin District. The environmental characteristics of the studied area are briefly discussed. The results of this study could serve as baseline information for assessing and monitoring the risk of filariasis disease in Banyuasin which may help to develop preventive actions to halt disease transmission in the future.

\section{MATERIALS AND METHODS}

\section{Study area}

The research was conducted by collecting mosquitoes in two villages of filariasis endemic area in Banyuasin District, South Sumatra, Indonesia. The first studied area was Sedang Village located in Suak Tapeh Sub-district $\left(2^{\circ}\right.$ $49.395^{\prime}$ South and $104^{\circ} 25.381^{\prime}$ East longitude) with the altitude of 10 meters above the sea level. The second studied area was Muara Sugih Village in Tanjung Lago Sub-district located at $2^{\circ} 47.048^{\prime}$ South and $104^{\circ} 45.731^{\prime}$ East longitude with the altitude of 12 meters above the sea level (Figure 1). The landscapes of studied area are dominated by water bodies such as swamp, river, rice field and farm (Figure 2). Sedang Village is surrounded by water bodies which constantly inundating to form pool-alike landscapes with aquatic plants covering the surfaces, indicating the characteristics of the swamps with mosaic of plantations of rubber trees and oil palm (Figure 2.A). It differs with Muara Sugih Village which consists of rivers, tidal rice fields, and oil palm plantations characterized by flowing water in primary and secondary drainage canals used to drain the rice fields (Figure 2.B).

The different characteristics of land use and hydrological system between Sedang Village and Muara Sugih do not differentiate the physical characteristics of both studied-area. Table 1 shows that the average temperature and humidity in Sedang Village and Muara Sugih Village are relatively similar with difference are less than $\pm 2{ }^{\circ} \mathrm{C}$ and $\pm 2 \%$, respectively. In term of altitude, both study areas are classified as lowland which is suitable for mosquitoes' breeding and habitat (Costa et al. 2010).

\section{Mosquitoes collection method}

The study was conducted in four months from December 2016 to March 2017 with one collection time per month. The mosquito collection was done using Indoor and Outdoor Human Landing Collection method (HLC) for 12 hours between 18.00 and 06.00 the following day by six groups of enumerator. Three groups collected mosquitoes that were biting and resting in indoor condition and three groups collected mosquitoes that were biting and resting in outdoor condition. The biting mosquitoes were collected using aspirator for 40 minutes per hour and the resting mosquitoes were collected using aspirators for 10 minutes per hour. All research activities had been approved by the Ethics Team of Sriwijaya University, Indonesia (Ethical Access Certificate No. 522 / kepkrsmhfkunsri / 2016).

\section{The identification of mosquitoes and data analysis}

All female mosquitoes were identified using the Rampa and Wharton identification book (Pratiwi et al. 2018) and habitat characteristics were also recorded. Species diversity and composition were then analyzed based on following parameters including indexes of abundance, frequency, and dominance (Sugiarto et al. 2017). Such parameters are formulated as follow:

$$
\begin{aligned}
& \text { Abundance }=\frac{\sum \text { mosquitoes are captured per species by certain methods }}{\sum \text { all mosquitoes caught with certain methods }} \times 100 \% \text { (1) } \\
& \text { Frequency }=\frac{\sum \text { arrests containing certain species }}{\sum \text { all certain arrests in the same way }}(2)
\end{aligned}
$$

Dominance Rate $=$ frequency $\mathrm{x}$ abundance (3)

Resting rate $=\frac{\sum \text { resting mosquitos of certain caught species }}{\sum \text { all caught resting mosquitos }} \times 100 \%$ (4) 

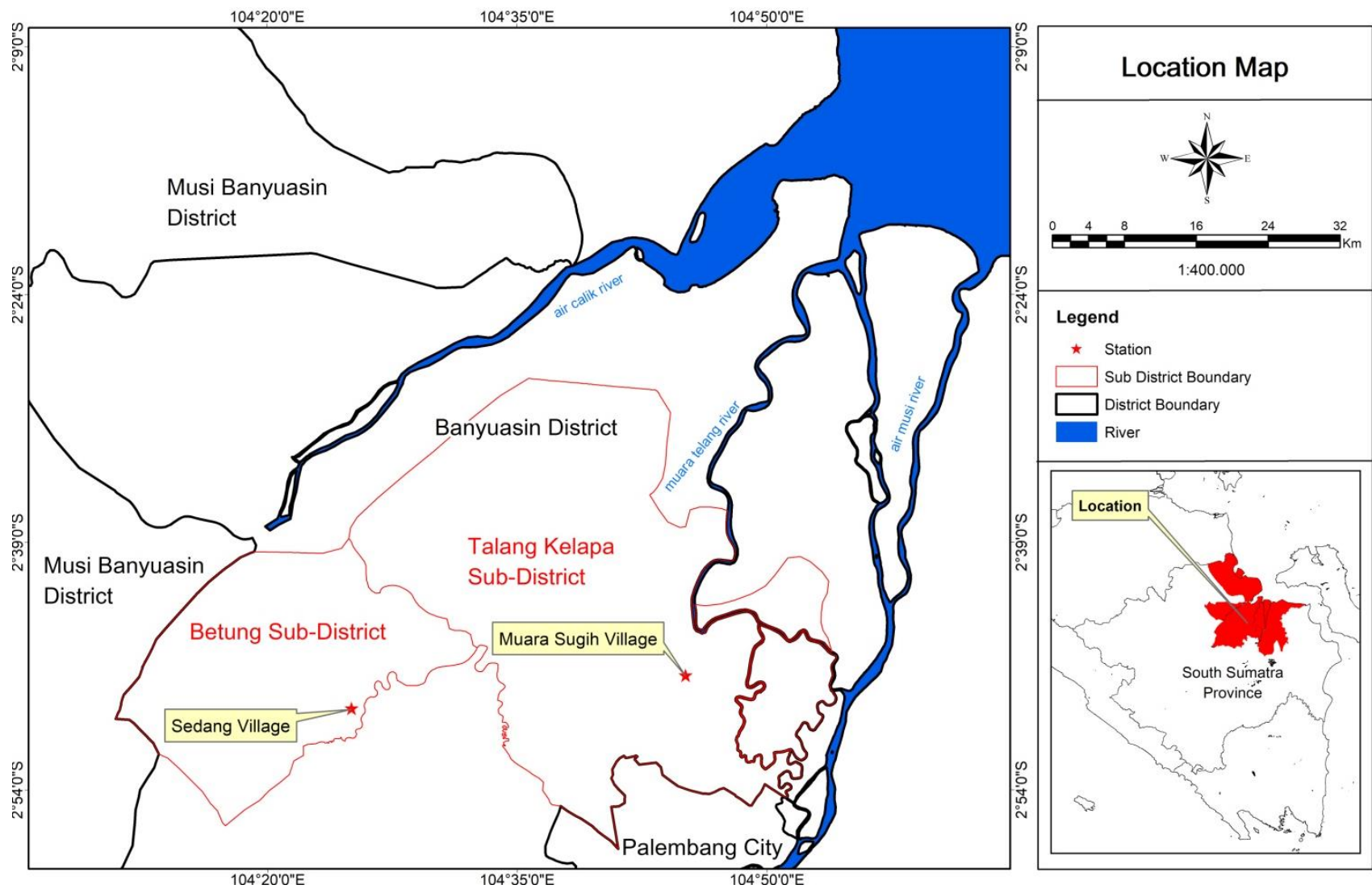

Figure 1. Location of study area at Sedang Village and Muara Sugih Village, Banyuasin District, South Sumatra, Indonesia
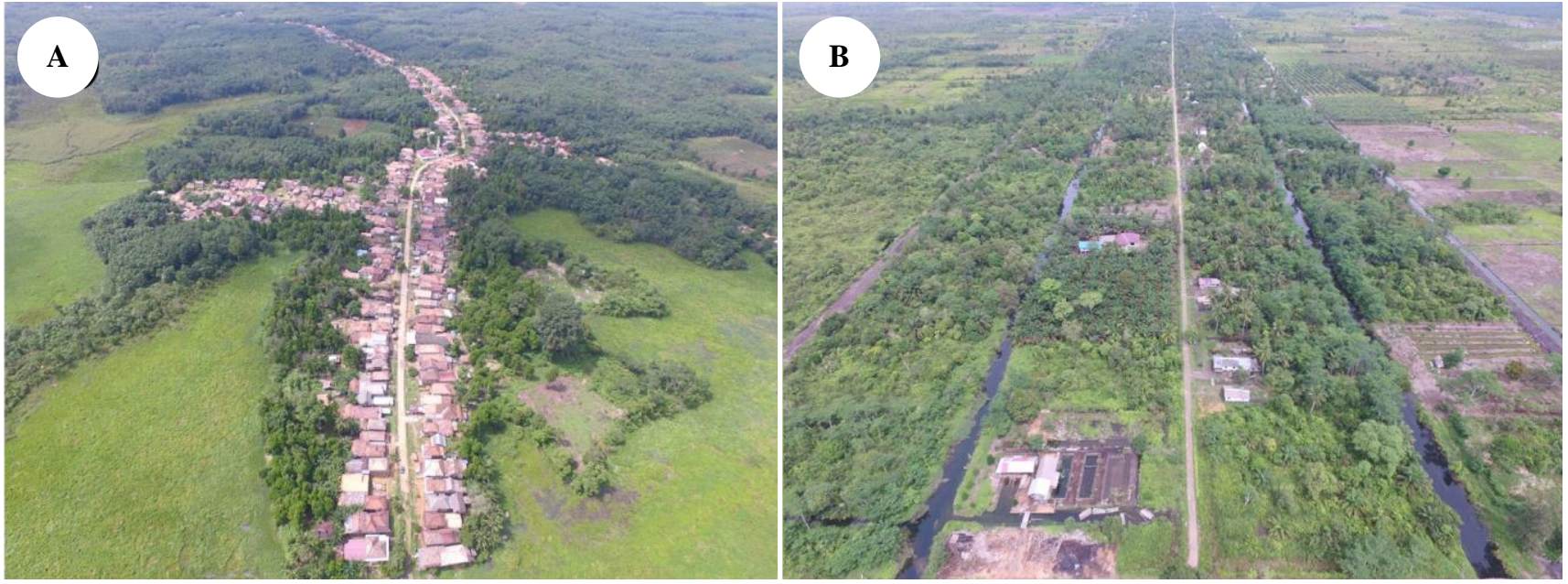

Figure 2. Landscape of (A) Sedang Village, and (B) Muara Sugih Village, Banyuasin District, South Sumatra, Indonesia

Table 1. Environmental characteristics of Sedang Village and Muara Sugih Village in Banyuasin District, South Sumatra, Indonesia

\begin{tabular}{lll}
\hline \multicolumn{1}{c}{ Variable } & \multicolumn{1}{c}{ Sedang Village } & \multicolumn{1}{c}{ Muara Sugih Village } \\
\hline Location & $2^{0} 49.395^{\prime}$ S and $104^{0} 25.381^{\prime}$ East longitude & $2^{0} 47.048^{\prime}$ S and $104^{0} 45.731^{\prime}$ East longitude \\
Altitude & 10 meters above sea level & 12 meters above sea level \\
Water bodies & Tidal swamps & Rivers, paddy fields \\
Temperature & $27,14 \pm 1,96^{\circ} \mathrm{C}$ & $25,64+1,46^{\circ} \mathrm{C}$ \\
Humidity & $91,18 \pm 5,35 \%$ & $86,92 \pm 11,897 \%$ \\
Aquatic plant dominant & Pistia stratiotes & Oryza sativa \\
Land use & Rubber and oil palm plantations & Rice fields \\
\hline
\end{tabular}




\section{RESULTS AND DISCUSSION}

\section{The collections of mosquitoes}

A total of 8239 mosquitoes were successfully collected during the fieldwork period, consisting of 12 genera: Mansonia (53.25\%), Culex (37.17\%), Anopheles (2.35\%), Aedes (4.84\%), Armigeres (0.53\%), Triptoides (0.25\%), Ochleratus $(0.10 \%)$, Mimomyia (0.06\%), Malaya $(0.23 \%)$, Topomyia $(0.01 \%)$, Lutzia $(0.11 \%)$, and Udaya $(0.01 \%)$. The 12 genera consist of 38 species including 10 species of Culex, 8 species of Aedes, 6 species of Mansonia, 5 species of Anopheles, 2 species of Malaya, and each one species from genus Armigeres, Triptoides, Ochleratus, Miomyia, Topomyia, Lutzia, and Udaya. The detailed number of mosquitoes and percentages of each genus were shown in Table 2.

If differentiated based on studied area, there were 10 genera consisting of 32 species of mosquitoes collected in Sedang Village, while in Muara Sugih Village, the genera were only 8 with 22 species. There were 16 species collected in both studied areas, which are Ma. dives, Ma. indiana, Ma. annulata, Ma. bonneae, Ma. uniformis, Och. fv. palliens, Cx. quinquefasciatus, Cx. tritaeniorhynchus, Cx. fuscocephalus, Cx. bitaeniorhycus, Cx. hutchinsoni, Cx. vishnui, Cx. gelidus, Ae. albolineatus, Ae. albopictus, and Ae. aegypti. Figure 3 shows detailed occurrence of mosquito species in the studied areas.

In term of total number of collected mosquitoes, the abundance of mosquitoes in Sedang Village is higher than the abundance of mosquitoes in Muara Sugih Village. There were approximately 4613 mosquitoes collected in Sedang Village, while in Muara Sugih there were only 3626 mosquitoes. Table 2 shows that the most dominant genus in both studied area are different in which Mansonia is the most dominant genus in Sedang Village, while in Muara Sugih Village, Culex is the most dominant.
Interestingly, there is an opposite pattern of dominant genus between two study areas in which a dominant genus in a village has a low number and percentage in the other village and vice versa. For example, there were $3.14 \%$ of Mansonia detected in Muara Sugih, while Culex comprised 3.09\% of total mosquitoes in Sedang Village. Other species have medium level of occurrence in both studied areas such as Aedes, but it has higher number collected in Muara Sugih Village than in Sedang Village. The rest genera relatively have similar numbers for both studied-areas. The findings of the diversity from two different studied areas provide baseline information on the distribution of mosquitoes in Banyuasin District.

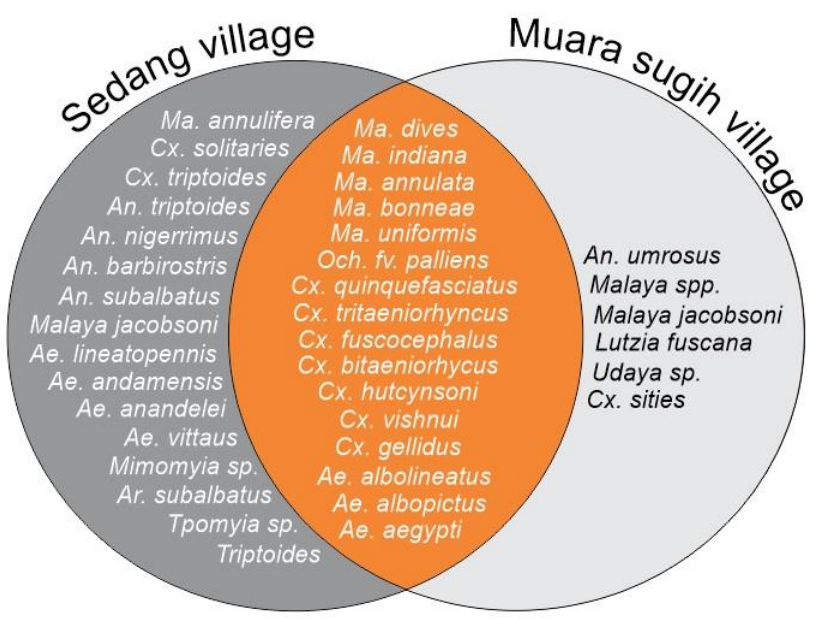

Figure 3. Species composition of mosquitoes at study areas of two villages in Banyuasin District, South Sumatra, Indonesia

Table 2. Genus diversity and abundance of mosquitoes in two studied areas in Sedang Village and Muara Sugih Village, Banyuasin District, South Sumatra, Indonesia

\begin{tabular}{|c|c|c|c|c|c|c|}
\hline \multirow[b]{2}{*}{ Genera } & \multicolumn{3}{|c|}{ Abundance in number } & \multicolumn{3}{|c|}{ Abundance in percentage $(\%)$} \\
\hline & Total & $\begin{array}{l}\text { Sedang } \\
\text { Village } \\
\end{array}$ & $\begin{array}{c}\text { Muara Sugih } \\
\text { Village }\end{array}$ & Total & $\begin{array}{l}\text { Sedang } \\
\text { Village } \\
\end{array}$ & $\begin{array}{c}\text { Muara Sugih } \\
\text { Village }\end{array}$ \\
\hline Mansonia & 4435 & 4176 & 259 & 53.25 & 50.68 & 3.14 \\
\hline Culex & 3096 & 255 & 2841 & 37.17 & 3.09 & 34.48 \\
\hline Anopheles & 196 & 82 & 114 & 2.35 & 0.99 & 1.38 \\
\hline Aedes & 403 & 18 & 385 & 4.84 & 0.22 & 4.67 \\
\hline Armigeres & 44 & 44 & 0 & 0.53 & 0.53 & 0 \\
\hline Triptoides & 21 & 21 & 0 & 0.25 & 0.25 & 0 \\
\hline Ochlerotatus & 9 & 7 & 2 & 0.10 & 0.08 & 0.02 \\
\hline Mimomyia & 5 & 5 & 0 & 0.06 & 0.06 & 0 \\
\hline Malaya & 19 & 4 & 15 & 0.23 & 0.05 & 0.18 \\
\hline Lutzia & 9 & 0 & 9 & 0.11 & 0 & 0.11 \\
\hline Udaya & 1 & 0 & 1 & 0.01 & 0 & 0.01 \\
\hline Topomyia & 1 & 1 & 0 & 0.01 & 0.01 & 0 \\
\hline Total & 8239 & 4613 & 3626 & 100 & 55.99 & 44.01 \\
\hline
\end{tabular}


Table 3. Species diversity and abundance of mosquitoes in two studied areas in Sedang Village and Muara Sugih Village, Banyuasin District, South Sumatra, Indonesia

\begin{tabular}{|c|c|c|c|c|c|}
\hline \multirow[b]{2}{*}{ Genera } & \multirow[b]{2}{*}{ Species } & \multicolumn{2}{|c|}{ Abundance in number } & \multicolumn{2}{|c|}{ Abundance in percentages $(\%)$} \\
\hline & & Sedang Village & $\begin{array}{c}\text { Muara Sugih } \\
\text { Village }\end{array}$ & Sedang Village & $\begin{array}{c}\text { Muara Sugih } \\
\text { Village }\end{array}$ \\
\hline \multirow{6}{*}{ Mansonia } & Ma. annulifera & 2228 & 0 & 27.04 & 0.00 \\
\hline & Ma. uniformis & 1022 & 135 & 12.40 & 1.64 \\
\hline & Ma. indiana & 909 & 7 & 11.03 & 0.08 \\
\hline & Ma. dives & 15 & 92 & 0.18 & 1.12 \\
\hline & Ma. bonneae & 1 & 24 & 0.01 & 0.29 \\
\hline & Ma. annulata & 1 & 1 & 0.01 & 0.01 \\
\hline \multirow{10}{*}{ Culex } & Cx. quinquefasciatus & 93 & 874 & 1.13 & 10.61 \\
\hline & Cx. gelidus & 80 & 125 & 0.97 & 1.52 \\
\hline & Cx. vishnui & 34 & 1073 & 0.41 & 13.02 \\
\hline & Cx. tritaeniorhynchus & 17 & 437 & 0.21 & 5.30 \\
\hline & Cx. fuscocephalus & 16 & 182 & 0.19 & 2.21 \\
\hline & Cx. tripteroides & 8 & 0 & 0.10 & 0.00 \\
\hline & $C x$. solitaries & 5 & 0 & 0.06 & 0.00 \\
\hline & Cx. bitaeniorhynchus & 1 & 1 & 0.01 & 0.01 \\
\hline & Cx. hutcynsoni & 1 & 9 & 0.01 & 0.11 \\
\hline & Cx. sitiens & 0 & 140 & 0.00 & 1.70 \\
\hline \multirow{5}{*}{ Anopheles } & An. triptoides & 51 & 0 & 0.62 & 0.00 \\
\hline & An. barbirostris & 16 & 0 & 0.19 & 0.00 \\
\hline & An. nigerrimus & 12 & 0 & 0.15 & 0.00 \\
\hline & An. subalbatus & 3 & 0 & 0.04 & 0.00 \\
\hline & An. umbrosus & 0 & 114 & 0.00 & 1.38 \\
\hline \multirow{8}{*}{ Aedes } & Ae. aegypti & 4 & 62 & 0.05 & 0.75 \\
\hline & Ae. albopictus & 3 & 6 & 0.04 & 0.07 \\
\hline & Aedes sp & 2 & 1 & 0.02 & 0.01 \\
\hline & Ae. albolineatus & 2 & 1 & 0.02 & 0.01 \\
\hline & Ae. annandalei & 2 & 0 & 0.02 & 0.00 \\
\hline & Ae. vittatus & 1 & 0 & 0.01 & 0.00 \\
\hline & Ae. lineatopennis & 1 & 0 & 0.01 & 0.00 \\
\hline & Ae. andamanensis & 3 & 315 & 0.04 & 3.82 \\
\hline Armigeres & Armigeres subalbatus & 44 & 0 & 0.53 & 0.00 \\
\hline Triptoides & Triptoides & 21 & 0 & 0.25 & 0.00 \\
\hline Ochlerotatus & Och. fv. palllens & 7 & 2 & 0.08 & 0.02 \\
\hline Mimomyia & Mimomyia sp & 5 & 0 & 0.06 & 0.00 \\
\hline \multirow{2}{*}{ Malaya } & Malaya jacobsoni & 4 & 10 & 0.05 & 0.12 \\
\hline & Malaya sp & 0 & 5 & 0.00 & 0.06 \\
\hline Lutzia & Lutzia fuscana & 0 & 9 & 0.00 & 0.11 \\
\hline Udaya & Udaya $\mathrm{sp}$ & 0 & 1 & 0.00 & 0.01 \\
\hline Topomyia & Topomyia & 1 & 0 & 0.01 & 0.00 \\
\hline
\end{tabular}

\section{Biting behavior of collected mosquitoes}

In Sedang Village, the outdoor and indoor biting behavior of collected mosquitoes is dominated by genus Mansonia. There are four species of Mansonia namely: Ma. annulifera, Ma. uniformis, Ma. indiana, and Ma. dives with the most abundant species is Mansonia annulifera with $46.27 \%$ and $48.91 \%$ in outdoor and indoor respectively, followed by Ma. uniformis (25.84\% and $18.28 \%)$ and Ma. indiana (18.47\% and 25.39). Ma. dives is the least abundant of Mansonia $(0.21 \%$ and $0,04 \%)$ captured in outdoor and indoor condition.

Cx. quinquefasciatus and Armigeres subalbatus are the only species outside the Mansonia spp. genus which have high biting activities in outdoor condition with approximately $2.59 \%$ and $1.89 \%$ of total collected mosquitoes, respectively. Cx. gelidus is higher in abundance in indoor than outdoor while $C x$. quinquefasciatus has less biting activity in indoor than outdoor.

In term of dominance rate of collected mosquitoes, $M a$. annulifera has the highest dominant rate by having 38.56 and 36.68 of biting activities in indoor and outdoor condition respectively, followed by Ma. uniformis, Ma. indiana, and $C x$. quinquefasciatus. In term of frequency of biting activities Ma. uniformis has the highest frequency with 0.62 and 0.90 in indoor and outdoor respectively, followed by Ma. annulifera ( 0.75 and 0.83 ). 
Table 4. Data on the abundance, frequency, and dominance of biting mosquitoes in Sedang Village, Banyuasin District, South Sumatra, Indonesia

\begin{tabular}{|c|c|c|c|c|c|c|c|}
\hline \multirow{2}{*}{ Genus } & \multirow{2}{*}{ Species } & \multicolumn{3}{|c|}{ Outdoor } & \multicolumn{3}{|c|}{ Indoor } \\
\hline & & Abundance (\%) & Frequency & Dominance & Abundance (\%) & Frequency & Dominance \\
\hline \multirow[t]{6}{*}{ Mansonia } & Ma. annulifera & 46.27 & 0.83 & 38.56 & 48.91 & 0.75 & 36.68 \\
\hline & Ma. uniformis & 25.84 & 0.90 & 23.15 & 18.28 & 0.62 & 11.42 \\
\hline & Ma. indiana & 18.47 & 0.75 & 13.85 & 25.39 & 0.62 & 15.87 \\
\hline & Ma. dives & 0.21 & 0.06 & 0.01 & 0.29 & 0.04 & 0.01 \\
\hline & Ma. bonneae & 0 & 0 & 0 & 0 & 0 & 0 \\
\hline & Ma. annulata & 0 & 0 & 0 & 0 & 0 & 0 \\
\hline \multirow[t]{10}{*}{ Culex } & Cx. quinquefasciatus & 2.60 & 0.35 & 0.92 & 1.58 & 0.23 & 0.36 \\
\hline & Cx. gelidus & 0.98 & 0.16 & 0.16 & 1.77 & 0.21 & 0.37 \\
\hline & Cx. vishnui & 0.77 & 0.12 & 0.09 & 0.39 & 0.04 & 0.01 \\
\hline & Cx. tritaeniorhynchus & 0.35 & 0.06 & 0.02 & 0.69 & 0.06 & 0.04 \\
\hline & Cx. fuscocephalus & 0 & 0 & 0 & 0 & 0 & 0 \\
\hline & Cx. tripteroides & 0.28 & 0.04 & 0.01 & 0 & 0 & 0 \\
\hline & Cx. solitaries & 0 & 0 & 0 & 0 & 0 & 0 \\
\hline & Cx. bitaeniorhynchus & 0 & 0 & 0 & 0 & 0 & 0 \\
\hline & Cx. hutchinsoni & 0.07 & 0.02 & 0.001 & 0 & 0 & 0 \\
\hline & $C x$. sitien & 0 & 0 & 0 & 0 & 0 & 0 \\
\hline \multirow{5}{*}{ Anopheles } & An. triptoides & 0.77 & 0.12 & 0.09 & 0.98 & 0.04 & 0.04 \\
\hline & An. barbirostris & 0.14 & 0.04 & 0.006 & 0.49 & 0.08 & 0.04 \\
\hline & An. nigerrimus & 0.35 & 0.06 & 0.02 & 0.19 & 0.04 & 0.01 \\
\hline & An. subalbatus & 0 & 0 & 0 & 0 & 0 & 0 \\
\hline & An. umbrosus & 0 & 0 & 0 & 0 & 0 & 0 \\
\hline \multirow[t]{8}{*}{ Aedes } & Ae. aegypti & 0 & 0 & 0 & 0 & 0 & 0 \\
\hline & Ae. albopictus & 0.07 & 0.02 & 0.001 & 0 & 0 & 0 \\
\hline & Aedes sp & 0 & 0 & 0 & 0 & 0 & 0 \\
\hline & Ae. albolineatus & 0 & 0 & 0 & 0 & 0 & 0 \\
\hline & Ae. annandalei & 0 & 0 & 0 & 0 & 0 & 0 \\
\hline & Ae. vittatus & 0 & 0 & 0 & 0 & 0 & 0 \\
\hline & Ae. lineatopennis & 0 & 0 & 0 & 0 & 0 & 0 \\
\hline & Ae. andamanensis & 0 & 0 & 0 & 0 & 0 & 0 \\
\hline Armigeres & Armigeres subalbatus & 1.90 & 0.14 & 0.28 & 0.79 & 0.08 & 0.06 \\
\hline Triptoides & Triptoides & 0.56 & 0.04 & 0.02 & 0.19 & 0.02 & 0.004 \\
\hline Ochlerotatus & Och. fv. palllens & 0.140449 & 0.02 & 0.003 & 0 & 0 & 0 \\
\hline Mimomyia & Mimomyia sp. & 0.070225 & 0.02 & 0.001 & 0 & 0 & 0 \\
\hline Malaya & $\begin{array}{l}\text { Malaya jacobsoni } \\
\text { Malaya sp }\end{array}$ & 0.140449 & 0.12 & 0.02 & 0 & 0 & 0 \\
\hline Lutzia & Lutzia fuscana & 0 & 0 & 0 & 0 & 0 & 0 \\
\hline Udaya & Udaya sp. & 0 & 0 & 0 & 0 & 0 & 0 \\
\hline Topomyia & Topomyia sp. & 0 & 0 & 0 & 0 & 0 & 0 \\
\hline
\end{tabular}

In Muara Sugih Village, Culex dominates the collected mosquitoes with 1293 and 540 individuals captured in outdoor and indoor, respectively. To be more specific, $C x$. vishnui and $C x$. quinquefasciatus are the most abundant species captured in outdoor and indoor, respectively. $C x$. vishnui has frequency of 0.54 and 0.48 in outdoor and indoor respectively, in which $C x$. quinquefasciatus has the highest frequency of biting activity both outdoor and indoor with frequency rates of 0.71 and 0.73 , respectively. The frequency index indicates that $C x$. quinquefasciatus has higher intensity of encounter compared to $C x$. vishnui during the fieldwork period. The other species of Culex spp. which have high occurrence and abundance including $C x$. tritaeniorhynchus, $C x$. sitien, and $C x$. fuscocephalus but they have lower frequency than $C x$. vishnui and $C x$. quinquefasciatus, indicating a lower intensity of presences of these species compared to $C x$. vishui and $C x$. quinquefasciatus.

Mansonia spp that dominates mosquitoes in Sedang Village have lower percentages of occurrence in Muara Sugih Village compared to Culex spp. There is only $7.35 \%$ and $7.58 \%$ of Mansonia spp recorded in Muara Sugih in outdoor and indoor biting activities, respectively, while there are $80.20 \%$ and $69.13 \%$ of Culex spp in outdoor and indoor biting activities, respectively. Moreover, Ma. bonneae and Ma. annulata which are not found in Sedang Village, yet they occur in Muara Sugih, providing additional distribution of Mansonia spp. Other species showing high abundance and dominance after Culex spp. including An. umbrosus and Ae. Aegypti. Detailed information on abundance, frequency, and dominance recorded mosquitoes in Muara Sugih Village is shown in Table 5 . 
Table 5. Data on the abundance, frequency, and dominance of biting mosquitoes in Muara Sugih Village, Banyuasin District, South Sumatra, Indonesia

\begin{tabular}{|c|c|c|c|c|c|c|c|}
\hline \multirow[b]{2}{*}{ Genera } & \multirow[b]{2}{*}{ Species } & \multicolumn{3}{|c|}{ Outdoor } & \multicolumn{3}{|c|}{ Indoor } \\
\hline & & $\begin{array}{c}\text { Abundance } \\
(\%)\end{array}$ & Frequency & Dominance & $\begin{array}{c}\text { Abundance } \\
(\%)\end{array}$ & Frequency & Dominance \\
\hline \multirow{6}{*}{ Mansonia } & Ma. annulifera & 0.00 & 0.00 & 0.00 & 0.00 & 0.00 & 0.00 \\
\hline & Ma. uniformis & 3.25 & 0.31 & 1.01 & 4.81 & 0.25 & 1.20 \\
\hline & Ma. indiana & 0.39 & 0.04 & 0.02 & 0.00 & 0.00 & 0.00 \\
\hline & Ma. dives & 3.17 & 0.31 & 0.99 & 1.48 & 0.10 & 0.15 \\
\hline & Ma. bonneae & 0.54 & 0.08 & 0.04 & 1.11 & 0.10 & 0.12 \\
\hline & Ma. annulata & 0.00 & 0.00 & 0.00 & 0.18 & 0.02 & 0.003 \\
\hline \multirow[t]{10}{*}{ Culex } & Cx. quinquefasciatus & 24.28 & 0.71 & 17.20 & 29.26 & 0.73 & 21.33 \\
\hline & $C x$. gelidus & 4.41 & 0.35 & 1.56 & 1.67 & 0.17 & 0.28 \\
\hline & Cx. vishnui & 30.63 & 0.54 & 16.59 & 23.15 & 0.48 & 11.09 \\
\hline & Cx. tritaeniorhynchus & 13.38 & 0.54 & 7.25 & 7.47 & 0.31 & 2.31 \\
\hline & Cx. fuscocephalus & 2.32 & 0.12 & 0.29 & 2.59 & 0.14 & 0.38 \\
\hline & $C x$. tripteroides & 0.00 & 0.00 & 0.00 & 0.00 & 0.00 & 0.00 \\
\hline & $C x$. solitaries & 0.00 & 0.00 & 0.00 & 0.00 & 0.00 & 0.00 \\
\hline & Cx. bitaeniorhynchus & 0.00 & 0.00 & 0.00 & 0.00 & 0.00 & 0.00 \\
\hline & Cx. hutchinsoni & 0.31 & 0.04 & 0.013 & 0.18 & 0.02 & 0.004 \\
\hline & Cx. sitiens & 4.87 & 0.17 & 0.81 & 4.81 & 0.08 & 0.40 \\
\hline \multirow[t]{5}{*}{ Anopheles } & An. triptoides & 0.00 & 0.00 & 0.00 & 0.00 & 0.00 & 0.00 \\
\hline & An. barbirostris & 0.00 & 0.00 & 0.00 & 0.00 & 0.00 & 0.00 \\
\hline & An. nigerrimus & 0.00 & 0.00 & 0.00 & 0.00 & 0.00 & 0.00 \\
\hline & An. subalbatus & 0.00 & 0.00 & 0.00 & 0.00 & 0.00 & 0.00 \\
\hline & An. umbrosus & 4.95 & 0.29 & 1.44 & 3.33 & 0.14 & 0.49 \\
\hline \multirow[t]{8}{*}{ Aedes } & Ae. aegypti & 2.86 & 0.14 & 0.42 & 1.48 & 0.10 & 0.15 \\
\hline & Ae. albopictus & 0.15 & 0.02 & 0.003 & 0.74 & 0.06 & 0.05 \\
\hline & Ae. lineatopennis & 0.00 & 0.00 & 0.00 & 0.00 & 0.00 & 0.00 \\
\hline & Ae. albolineatus & 0.00 & 0.00 & 0.00 & 0.00 & 0.00 & 0.00 \\
\hline & Ae. annandalei & 0.00 & 0.00 & 0.00 & 0.00 & 0.00 & 0.00 \\
\hline & Ae. vittatus & 0.00 & 0.00 & 0.00 & 0.00 & 0.00 & 0.00 \\
\hline & Ae. andamanensis & 4.41 & 0.29 & 1.29 & 17.04 & 0.33 & 5.68 \\
\hline & Aedes sp. & 0.00 & 0.00 & 0.00 & 0.18 & 0.02 & 0.004 \\
\hline Armigeres & Armigeres subalbatus & 0.00 & 0.00 & 0.00 & 0.00 & 0.00 & 0.00 \\
\hline Triptoides. & Triptoides & 0.00 & 0.00 & 0.00 & 0.00 & 0.00 & 0.00 \\
\hline Ochlerotatus & Och. fv. palllens & 0.00 & 0.00 & 0.00 & 0.00 & 0.00 & 0.00 \\
\hline Mimomyia & Mimomyia sp. & 0.00 & 0.00 & 0.00 & 0.00 & 0.00 & 0.00 \\
\hline \multirow[t]{2}{*}{ Malaya } & Malaya jacobsoni & 0.08 & 0.02 & 0.002 & 0.00 & 0.00 & 0.00 \\
\hline & Malaya spp. & 0.00 & 0.00 & 0.00 & 0.18 & 0.02 & 0.004 \\
\hline Lutzia & Lutzia fuscana & 0.00 & 0.00 & 0.00 & 0.37 & 0.02 & 0.008 \\
\hline Udaya & Udaya sp. & 0.00 & 0.00 & 0.00 & 0.00 & 0.00 & 0.00 \\
\hline Topomyia & Topomyia sp. & 0.00 & 0.00 & 0.00 & 0.00 & 0.00 & 0.00 \\
\hline
\end{tabular}

\section{Resting behavior of collected mosquitoes}

Table 6 shows resting behavior of collected mosquitoes in Sedang Village. Ma. annulifera which has the highest abundance, frequency, and dominance species of biting behaviors in Sedang Village also relatively has similar percentages of outdoor and indoor resting activities. The high abundance of resting mosquitoes was followed by $M a$, uniformis, and Ma. indiana. On the other hand, Ma. uniformis, $C x$. quinquefasciatus, $C x$. gelidus which show higher biting activities in outdoor than indoor, on the contrary, they have higher indoor resting activities than outdoor ones, indicating that resting behavior is not correlated with biting behavior. However, Ma. indiana shows different result by having similar condition in resting and biting activities in Sedang Village.

In Muara Sugih Village, data of resting behavior of collected mosquitoes is shown in Table 7. Cx. vishnui is the most dominant and abundant species in term of resting activities with outdoor resting is more prevalent than indoor resting. This behavior is correlated with biting behavior of $C x$. vishnui which has higher outdoor biting behavior than indoor. Other species, $C x$. quinquefasciatus which is the second most abundant species in Muara Sugih Village has relatively higher resting activities in indoor than in outdoor. This result is in accordance with the resting behavior of $C x$. quinquefasciatus in Sedang Village. Other species such as $C x$. fuscocephalus and An. umbrosus show similar behavior of biting and resting. However, other species including $C x$. sitiens, Cx. gelidus, Ae. aegypti and $A e$. andamanensis show different results between resting activities and biting activities, which are similar to the behavior of Ma. uniformis and $C x$. quinquefasciatus in Sedang Village. 
Table 6. Data on the abundance of resting mosquitoes in Sedang Village, Banyuasin District, South Sumatra, Indonesia

\begin{tabular}{|c|c|c|c|}
\hline Genera & Species & $\begin{array}{c}\text { Outdoor } \\
(\%)\end{array}$ & $\begin{array}{c}\text { Indoor } \\
(\%)\end{array}$ \\
\hline \multirow[t]{6}{*}{ Mansonia } & Ma. annulifera & 50.45 & 48.16 \\
\hline & Ma. uniformis & 19.77 & 23.42 \\
\hline & Ma. indiana & 17.62 & 18.13 \\
\hline & Ma. dives & 0.36 & 0.47 \\
\hline & Ma. bonneae & 0.09 & 0.00 \\
\hline & Ma. annulata & 0.00 & 0.09 \\
\hline \multirow[t]{10}{*}{ Culex } & $C x$. quinquefasciatus & 1.16 & 2.55 \\
\hline & $C x$. gelidus & 2.86 & 1.51 \\
\hline & Cx. vishnui & 1.16 & 0.56 \\
\hline & Cx. tritaeniorhynchus & 0.45 & 0.00 \\
\hline & Cx. fuscocephalus & 0.81 & 0.66 \\
\hline & Cx. tripteroides & 0.18 & 0.19 \\
\hline & Cx. solitaries & 0.45 & 0.00 \\
\hline & Cx. bitaeniorhynchus & 0.09 & 0.00 \\
\hline & Cx. hutchinsoni & 0.00 & 0.00 \\
\hline & Cx. sitiens & 0.00 & 0.00 \\
\hline \multirow[t]{5}{*}{ Anopheles } & An. triptoides & 0.81 & 1.98 \\
\hline & An. barbirostris & 0.45 & 0.38 \\
\hline & An. nigerrimus & 0.09 & 0.38 \\
\hline & An. subalbatus & 0.00 & 0.28 \\
\hline & An. umbrosus & 0.00 & 0.00 \\
\hline \multirow[t]{8}{*}{ Aedes } & Ae. aegypti & 0.18 & 0.19 \\
\hline & Ae. albopictus & 2.27 & 0.09 \\
\hline & Aedes sp & 0.09 & 0.09 \\
\hline & Ae. albolineatus & 0.09 & 0.09 \\
\hline & Ae. annandalei & 0.09 & 0.09 \\
\hline & Ae. vittatus & 0.00 & 0.00 \\
\hline & Ae. lineatopennis & 0.00 & 0.09 \\
\hline & Ae. andamanensis & 0.28 & 0.00 \\
\hline Armigeres & Armigeres subalbatus & 0.00 & 0.00 \\
\hline Triptoides & Triptoides & 0.45 & 0.00 \\
\hline Ochlerotatus & Och. fv. palllens & 0.18 & 0.00 \\
\hline Mimomyia & Mimomyia $s p$ & 0.18 & 0.19 \\
\hline \multirow[t]{2}{*}{ Malaya } & Malaya jacobsoni & 0.18 & 0.00 \\
\hline & Malaya $s p$ & 0.00 & 0.00 \\
\hline Lutzia & Lutzia fuscana & 0.00 & 0.00 \\
\hline Udaya & Udaya sp. & 0.00 & 0.00 \\
\hline Topomyia & Topomyia $s p$ & 0.00 & 0.00 \\
\hline
\end{tabular}

\section{Discussion}

Environmental characteristics of Banyuasin District provide suitable breeding place for mosquitoes. Both studied areas consist of wetland area but differ in the type of landscape and hydrological system either in the form of swamps, rice fields, and rivers. The climatic variables in term of air temperature and humidity in both studied areas also support the breeding and development of mosquitoes' larvae, resulting in high diversity of mosquito species (Amarasinghe and Weerakkodi 2014). In this study, there are 8239 mosquitoes are collected belong to 38 species and 12 genera such as Mansonia (53,83\%), Culex $(37,58 \%)$, Anopheles (2,38\%), Aedes (4,90\%), Armigeres (0,53\%), Tripteroides $(0,25 \%)$, Ochleratus $(0,11 \%)$, Mimomyia $(0,06 \%)$, Malaya $(0,23 \%)$, Topomyia $(0,01 \%)$, Lutzia $(0,11 \%)$ and Udaya $(0,01 \%)$.

Further investigation demonstrates that the distribution of mosquitoes' communities in Sedang Village differ with those in Muara Sugih Village where Mansonia spp is the highest number of collected mosquitoes in Sedang Village
Table 7. Data on the abundance of resting mosquitoes in Muara Sugih Village, Banyuasin District, South Sumatra, Indonesia

\begin{tabular}{|c|c|c|c|}
\hline Genera & Species & $\begin{array}{c}\text { Outdoor } \\
(\%)\end{array}$ & $\begin{array}{c}\text { Indoor } \\
(\%)\end{array}$ \\
\hline \multirow[t]{6}{*}{ Mansonia } & Ma. annulifera & 0.00 & 0.00 \\
\hline & Ma. uniformis & 3.92 & 3.42 \\
\hline & Ma. indiana & 0.17 & 0.00 \\
\hline & Ma. dives & 2.26 & 2.64 \\
\hline & Ma. bonneae & 0.61 & 0.62 \\
\hline & Ma. annulata & 0.00 & 0.00 \\
\hline \multirow[t]{10}{*}{ Culex } & Cx. quinquefasciatus & 19.15 & 28.26 \\
\hline & Cx. gelidus & 3.13 & 3.57 \\
\hline & Cx. vishnui & 31.24 & 29.97 \\
\hline & CX. tritaeniorhynchus & 11.58 & 14.13 \\
\hline & Cx. fuscocephalus & 6.96 & 9.01 \\
\hline & Cx. tripteroides & 0.00 & 0.00 \\
\hline & Cx. solitaries & 0.00 & 0.00 \\
\hline & Cx. bitaeniorhynchus & 0.09 & 0.00 \\
\hline & Cx. hutchinsoni & 0.35 & 0.00 \\
\hline & CX. sitiens & 2.52 & 3.41 \\
\hline \multirow[t]{5}{*}{ Anopheles } & An. triptoides & 0.00 & 0.00 \\
\hline & An. barbirostris & 0.00 & 0.00 \\
\hline & An. nigerrimus & 0.00 & 0.00 \\
\hline & An. subalbatus & 0.00 & 0.00 \\
\hline & An. umbrosus & 2.52 & 0.46 \\
\hline \multirow[t]{8}{*}{ Aedes } & Ae. aegypti & 0.00 & 2.64 \\
\hline & Ae. albopictus & 0.00 & 0.00 \\
\hline & Aedes sp & 0.00 & 0.00 \\
\hline & Ae. albolineatus & 0.09 & 0.00 \\
\hline & Ae. annandalei & 0.00 & 0.00 \\
\hline & Ae. vittatus & 0.00 & 0.00 \\
\hline & Ae. andamanensis & 14.45 & 0.00 \\
\hline & Ae. lineatopennis & 0.00 & 0.00 \\
\hline Armigeres & Armigeres subalbatus & 0.00 & 0.00 \\
\hline Triptoides & Triptoides & 0.00 & 0.00 \\
\hline Ochlerotatus & Och. fv. pallens & 0.17 & 0.00 \\
\hline Mimomyia & Mimomyia sp & 0.00 & 0.00 \\
\hline \multirow[t]{2}{*}{ Malaya } & Malaya jacobsoni & 0.26 & 0.93 \\
\hline & Malaya sp & 0.09 & 0.46 \\
\hline Lutzia & Lutzia fuscana & 0.35 & 0.46 \\
\hline Udaya & Udaya sp & 0.09 & 0.00 \\
\hline Topomyia & Topomyia sp & 0.00 & 0.00 \\
\hline
\end{tabular}

while Culex spp is the highest in Muara Sugih. Nonetheless, both studied areas have relatively high diversity of mosquito species in which the total genera in Sedang Village and Muara Sugih Village are 10 and 8 genera and the total of species are 32 and 22 species, respectively. The high diversity of mosquito in both studied areas reveal potential risk associated with the occurrence and transmission of vector-borne diseases (Manguin and Boete 2011). Although there are only few species potentially become the vector of infectious disease, it is really important to understand their diversity, composition and distribution in a filariasis endemic area such as in Banyuasin District.

There are many factors affecting the diversity of mosquitoes. Most important is the quality and the characteristic of environment, especially the water system (Mahmuda and Usman 2011). It is because mosquitoes' larvae entirely require aquatic habitats which develop themselves in water bodies. The water quality and characteristics determine species diversity and community 
composition of mosquitoes (Bashar et al. 2016). In Sedang Village, most of the water bodies are characterized as waterlogged areas that form pool-alike landscape with aquatic plants covering the surfaces. In Muara Sugih, the water bodies are in the form of primary and secondary drainage canals with the water is flowing. The water body's characteristics likely affect species diversity and community composition of mosquitoes. The logged water bodies such as in Sedang Village consists of higher diversity than the flowing water such as in Muara Sugih. These findings are in agreement with common knowledge that mosquitoes prefer stagnant water as breeding site than flowing water. However, it is different from the case of Culex spp which shows high activities in Muara Sugih which is characterized by flowing-water landscape. This finding provides new insight that Culex spp. is typically favor fresh and unpolluted water in which the water is contained inorganic ions such as $\mathrm{Na}_{+}, \mathrm{Mg}^{2+}, \mathrm{Ca}^{2+}, \mathrm{Cl}^{-} \mathrm{NO}^{3-}$, $\mathrm{SO}_{4}{ }^{2-}$ etc (Rydzanicz et al. 2016). This study which demonstrates the dominance of $C x$. vishnui and $C x$. quinquefasciatus in Muara Sugih Village indicates that these species prefer flowing water and primary drainage as breeding site.

The dominant species of mosquitoes in each studied area is likely also determined by water plant characteristics. In Sedang Village, most of the water bodies are covered with water plants which provide suitable place of breeding for Mansonia spp. A study states that Mansonioides can only breed in fresh water containing floating vegetation (Ghosh et al. 2006). To be more specific, Ma. annulifera, the most dominant species in Sedang Village, shows the preference water bodies covered with Pistia stratiotes than any weeds. Pistia stratiotes become suitable water plant supporting the breeding of Mansonia mosquitoes through attaching the Mansonia larvae on the roots of P. stratiotes and obtains oxygen from Aerenchyma cells of aquatic plants by inserting its serrated siphon (Gupta et al. 2010; Lounibos et al. 1990).

On the other hand, the landscape in Muara Sugih Village is characterized by rice fields with Oryza sativa as the dominant aquatic plant. Previous study reveals that flood-irrigated rice fields serve as breeding site for potential vector mosquitoes species, mainly the larvae of Culex, Anopheles and Aedes species (Dejenie et al. 2011). It is in accordance with the result of this study in which Culex spp is found as the most dominant genera in Muara Sugih which mostly consists of rice field with no other water plant covered the water bodies. The presence of paddy plant supports the breeding of Culex spp. Richards (2010) reports that there is a linear relationship between mosquitoes abundance of Culex spp with rice field density in which the higher is the density of paddy field the higher is mosquitoes abundance (Richards et al. 2010; Jacob et al. 2006). This is because the Urea fertilizer added onto paddy field can stimulate the oviposition attractant or stimulant of Culex species (Sunish et al. 2003).

Besides the diversity of mosquitoes is different between two studied areas, several species are found in both areas. The overlapping community composition includes 16 species, in which five species are the dominant species in both places, such as Ma. uniformis and Ma. indiana which are the dominant species in Sedang Village, and $C x$. quinquefasciatus, $C x$. vishnui, and $C x$. tritaeniorhynchus which are dominant in Muara Sugih Village. The presence of these species in both studied-area suggests that these species could breed under wide-range of physical characteristics of the environment in both studied-areas. On the other hand, the absence of several species indicates that environmental characteristics of each studied-area could not support the breeding of such mosquitoes. Nonetheless, other factors may contribute to the spread and transmission of infectious diseases. Further studies are therefore required to investigate the potential of these mosquitoes in transmitting diseases. Several reports find that Culex spp and Aedes spp are the vector for Japanese Encephalitis and Dengue Hemorraghic Fever, respectively. Meanwhile, Mansonia spp is reported as the vector for filariasis.

This study also reveals biting behavior of collected mosquitoes. The results show that the most dominant species obviously are also mosquitoes with the most biting activities. Host feeding behavior of mosquitoes has important implications for humans since the biting rhythms of mosquitoes can determine the periods of transmission risk and also serve as basic information for developing methods of personal protection against disease transmission or annoyance. The biting activities need to be studied because it allows an understanding of biting cycles of vector species, determining of nuisance level, and detecting the risk of disease transmission. In Sedang Village, most of the collected mosquitoes are Mansonia spp which could transmit the infected disease such as filariasis. It is in accordance with the fact that Sedang Village becomes the endemic area of filariasis (Banyuasin 2016). In Muara Sugih, Culex spp are the most dominant species found in the area which potentially transmit several diseases such as filariasis, Japanese encephalitis, etc. (Kauffman et al. 2017). The results of biting behavior of this study could serve as baseline information for assessment and monitoring to develop plausible strategies to prevent the risk of mosquito-based pathogen diseases transmission in Banyuasin.

The study of resting behavior conducted may also help to determine the category of mosquito. Endophilic mosquito is defined as mosquito that rest in indoor condition, inside a human dwelling, during the period between the end of blood-feeding and the onset of searching for an oviposition site. In contrast, the exophilic mosquitoes spend this period somewhere outside a human dwelling (Paaijmans and Thomas 2011). The resting behaviors for female mosquitoes are aimed to get a break in the following night after sucking blood, perhaps due to an increase in weight which made it difficult and dangerous to fly. Several observations suggest that various species of mosquitoes are approaching the host and waiting before they give a bite (Tuno et al. 2003). The results of this study show that the most dominant species in both studied areas have relatively similar resting area in indoor and outdoor condition. The results suggest that Mansonia spp and Culex spp can be categorized as exophilic mosquitoes except for $C x$. quinquefasciatus which may be categorized 
as endophilic. There are no behavior changes found during the research period.

To conclude, this study find that factors including environmental characteristic, hydrological system, and the presence of aquatic plant, likely related to the species diversity and community composition of mosquitoes in Banyuasin District. The physical parameters such as temperature, air humidity, and altitude may not contribute a lot to differentiate mosquito diversity due to both studied areas have similar physical characteristics. The logged water covered with Pistia stratiotes in Sedang Village facilitates the breeding of Mansonia, resulting in the dominance of Mansonia spp. The high density of rice field with flowing water in Muara Sugih Village contributes to a high number of Culex, Anopheles, and Aedes with Culex spp as the most dominant mosquitoes. The high diversity of Mansonia spp in Sedang Village is in agreement with the label of Sedang Village as the endemic area of filariasis triggered by the biting activities of Mansonia spp. The findings of this research may serve as an initial assessment in determining the potential of infectious disease transmitted in the studied area. Further research is required in the studied area to investigate whether the diversity increases the risk of transmission or reduces the transmission through dilution effect.

\section{ACKNOWLEDGEMENTS}

Authors acknowledge the contribution of Health Department of Banyuasin District, South Sumatra, Indonesia for the supports and cooperation during this research.

\section{REFERENCES}

Amarasinghe LD, Weerakkodi WGIS. 2014. Density and Diversity of Mosquito Larvae Associated With Rice Field and Marshland Habitats in Two Climatically Different Areas in Sri Lanka. Intl J Entomol Res 2 (2): 59-71.

Apiwathnasorn C, Samung Y, Prummongkol S, Asavanich A Komalamisra N, Mccall P. 2006. Bionomics studies of Mansonia mosquitoes inhabiting the peat swamp forest. Southeast Asian J Trop Med Publ Health 37 (2): 272-278.

Asare EO, Tompkins AM, Amekudzi LK, Ermert V, Redl R. 2016. Mosquito breeding site water temperature observations and simulations towards improved vector-borne disease models for Africa. Geospatial Health 11: 391.

Bashar K, Rahman MS, Nodi IJ, Howlader AJ. 2016. Species composition and habitat characterization of mosquito (Diptera: Culicidae) larvae in semi-urban areas of Dhaka, Bangladesh. Pathogen Glo Health 110 (2): 48-61

Beerntsen BT, James AA, Christensen BM. 2000. Genetics of mosquito vector competence. Microbiol Mol Biol Rev 64 (1): 115-137.

Chandra G. 2008. Nature limits filarial transmission. Parasit Vector 1 (1): 13.

Chaves LF, Hamer GL, Walker ED, Brown WM, Ruiz MO, Kitron UD. 2011. Climatic variability and landscape heterogeneity impact urban mosquito diversity and vector abundance and infection. Ecosphere 2 (6): $\operatorname{art70.}$

Costa EAP de A, Santos EM de M, Correia JC, Albuquerque CMR de. 2010. Impact of small variations in temperature and humidity on the reproductive activity and survival of Aedes aegypti (Diptera, Culicidae). Revista Brasileira de Entomologia 54 (3): 488-493.

Coulibaly Y, Dembele B, Diallo A, Kristensen S, Konate S, Dolo H, Dicko I, Sangare M, Keita F, Boatin BA, Traore A, Nutman TB,
Klion AD, Touré Y, Traore S. 2013. Wuchereria bancrofti transmission pattern in southern Mali prior to and following the institution of mass drug administration. Parasites Vectors 6 (1): 247.

Dejenie T, Yohannes M, Assmelash T. 2011. Characterization of mosquito breeding sites in and in the vicinity of tigray microdams. Ethiopian J Health Sci 21 (1): 57-66.

Dinas Kesehatan Banyuasin. 2016. Profil Dinas Kesehatan Kabupaten Banyuasin, Pangkalan Balai. Dinas Kesehatan Banyuasin, Banyuasin.

Ghosh A, Biswas D, Chatterjee SN, Bengal W. 2006. Host plant preference of Mansonia mosquitoes. J Aquat Pl Manag 44: 142-144.

Gupta R, Tripathi P, Kumar R, Sharma A, Mishra A. 2010. Pistia stratiotes (Jalkumbhi). Pharmacogn Rev 4 (8): 153.

Jacob BG, Shililu J, Muturi EJ, Mwangangi JM, Muriu SM, Funes J, Githure J, Regens JL, Novak RJ. 2006. Spatially targeting Culex quinquefasciatus aquatic habitats on modified land cover for implementing an Integrated Vector Management (IVM) program in three villages within the Mwea Rice Scheme, Kenya. Intl J Health Geogr 5: 18.

Kauffman E, Payne A, Franke MA, Schmid MA, Harris E, Kramer LD. 2017. Rearing of Culex spp. and Aedes spp. mosquitoes. Bio Protoc 7 (17): e2542.

Kementerian Kesehatan RI. 2016. Pusat Data dan Informasi Kementerian Kesehatan RI- Filariasis; Oktober Bulan Eliminasi Kaki Gajah (BELKAGA). 2016: 1-8.

Lounibos L.P, Escher R.L, Dewald L.B, Nishimura N, Larson V.L. 1990. Odonata associated with water lettuce (Pistia stratiotes L.) in south Florida. Odonatologica. 19 (4): 359-366.

Mahmuda A, Usman M. 2011. Preferred Breeding Sites of Different Mosquito Species in Sokoto. , (January).

Manguin S, Boete C. 2011. Global Impact of Mosquito Biodiversity, Human Vector-Borne Diseases and Environmental Change. In: The Importance of Biological Interactions in the Study of Biodiversity. IntechOpen Limited, London.

Paaijmans KP, Thomas MB. 2011. The influence of mosquito resting behaviour and associated microclimate for malaria risk. Malaria J 10: 1-7.

Pratiwi R, Anwar C, Hidayat R. 2018. Habitat characterization of Mansonia spp as Filariasis vector in Banyuasin, South Sumatra , Indonesia. 4: 1-5.

Rajakumar G, Abdul Rahuman A. 2011. Larvicidal activity of synthesized silver nanoparticles using Eclipta prostrata leaf extract against filariasis and malaria vectors. Acta Tropica 118 (3): 196-203.

Richards EE, Masuoka P, Brett-Major D, Smith M, Klein TA, Kim HC, Anyamba A, Grieco J. 2010. The relationship between mosquito abundance and rice field density in the Republic of Korea. Intl $\mathbf{J}$ Health Geogr 9 (Cdc): 1-10.

Roche B, Rohani P, Dobson AP, Guégan J-F. 2013. The impact of community organization on vector-borne pathogens. Amer Nat 181 (1): 1-11.

Rueda LM. 2008. Global diversity of mosquitoes (Insecta: Diptera: Culicidae) in freshwater. Hydrobiologia 595 (1): 477-487.

Rydzanicz K, Jawień P, Lonc E, Modelska M. 2016. Assessment of productivity of Culex spp. larvae (Diptera: Culicidae) in urban storm water catch basin system in Wrocław (SW Poland). Parasitol Res 115 (4): 1711-1720.

St. Laurent B, Supratman S, Asih PBS, Bretz D, Mueller J, Miller HC, Baharuddin A, Shinta, Surya A, Ngai M, Laihad F, Syafruddin D, Hawley WA, Collins FH, Lobo NF. 2016. Behaviour and molecular identification of Anopheles malaria vectors in Jayapura District, Papua Province, Indonesia. Malaria J 15 (1): 192.

Sugiarto, Hadi UK, Soviana S, Hakim L. 2017. Bionomics of Anopheles (Diptera: Culicidae) in a malaria endemic region of Sungai Nyamuk village, Sebatik Island, North Kalimantan, Indonesia. Acta Tropica 171: 30-36.

Sunish I, Rajendran R, Reuben R. 2003. The role of urea in the oviposition behaviour of Japanese encephalitis vectors in rice fields of South India. Mem Inst Oswaldo Cruz 98 (6): 789-791.

Tuno N, Tsuda Y, Takagi M, Swonkerd W. 2003. Pre- and postprandial mosquito resting behavior around cattle hosts. J Amer Mosquito Contr Assoc 19 (3): 211-219.

Vourc'h G, Plantard O, Morand S. 2012. How does biodiversity influence the ecology of infectious disease? In New Frontiers of Molecular Epidemiology of Infectious Diseases. Springer, Heidelberg.

Wijayanti SPM, Sunaryo S, Suprihatin S, McFarlane M, Rainey SM, Dietrich I, Schnettler E, Biek R, Kohl A. 2016. Dengue in Java, Indonesia: Relevance of mosquito indices as risk predictors. PLOS Neglect Trop Dis 10 (3): e0004500. 